\title{
Large-scale Production of Novel Porcine Circovirus Type 2d (PCV2d) Subunit Vaccine Using E. coli Platform
}

\author{
Sarawuth Noppiboon ${ }^{1}$, Thunyaluk Kerdboon ${ }^{1}$, Neeracha Lapanusorn ${ }^{1}$, Pisit \\ Ekkpongpaisit ${ }^{1}$, Sarah Slack ${ }^{2}$, Stefanie Frank ${ }^{2}$, and Lalintip Hocharoen ${ }^{1}$ \\ ${ }^{1}$ King Mongkut's University of Technology Thonburi \\ ${ }^{2}$ University College London
}

September 25, 2021

\begin{abstract}
Porcine Circovirus type 2d (PCV2d) is becoming the predominant PCV genotype and considerably affects the global pig industry. Nevertheless, currently no commercial PCV2d vaccine is available. Preventing and controlling the disease caused by PCV2d is therefore based on other genotype-based vaccines. However, their production platforms are laborious, limited in expression level and relatively expensive for veterinary applications. To address these challenges, we have developed a simple and cost-efficient platform for a novel PCV2d vaccine production platform, using fed-batch E. coli fermentation followed by cell disruption and filtration, and a single purification step via cation exchange chromatography. The process was developed at bench scale and then pilot scale where the PCV2d subunit protein yield was approximately $0.8 \mathrm{~g} / \mathrm{L}$ fermentation volume in a short production time. Moreover, we have successfully implemented this production process at two different sites, in Southeast Asia and Europe. This demonstrates transferability and the high potential for successful industrial production.
\end{abstract}

Running title: Large-scale PCV2d vaccine production

Sarawuth Noppiboon ${ }^{1}$, Thunyaluk Kerdboon ${ }^{1}$, Neeracha Lapanusorn ${ }^{1}$, Pisit Ekkpongpaisit ${ }^{1}$, Sarah Slack ${ }^{2}$, Stefanie Frank ${ }^{2}$, Lalintip Hocharoen ${ }^{1}$

${ }^{1}$ Bioprocess Research and Innovation Centre (BRIC), National Biopharmaceutical Facility (NBF), King Mongkut's University of Technology Thonburi (KMUTT), Bangkok, Thailand

${ }^{2}$ Department of Biochemical Engineering, University College London, Gower Street, London, WC1E 6BT, United Kingdom

Correspondence: Dr. Lalintip Hocharoen, Bioprocess Research and Innovation Centre (BRIC), National Biopharmaceutical Facility (NBF), King Mongkut's University of Technology Thonburi (KMUTT), Bangkok, Thailand.

Phone: (66)2 470 7361, Email: lalintip.hoc@kmutt.ac.th

Funding information: UK Research and Innovation 'Global Challenges Research Fund' grant BB/P02789X/1.

\section{Abstract}

Porcine Circovirus type 2d (PCV2d) is becoming the predominant PCV genotype and considerably affects the global pig industry. Nevertheless, currently no commercial PCV2d vaccine is available. Preventing and controlling the disease caused by PCV2d is therefore based on other genotype-based vaccines. However, 
their production platforms are laborious, limited in expression level and relatively expensive for veterinary applications. To address these challenges, we have developed a simple and cost-efficient platform for a novel PCV2d vaccine production platform, using fed-batch E. coli fermentation followed by cell disruption and filtration, and a single purification step via cation exchange chromatography. The process was developed at bench scale and then pilot scale where the PCV2d subunit protein yield was approximately $0.8 \mathrm{~g} / \mathrm{L}$ fermentation volume in a short production time. Moreover, we have successfully implemented this production process at two different sites, in Southeast Asia and Europe. This demonstrates transferability and the high potential for successful industrial production.

Key words: Large-scale, fed-batch fermentation, one-step purification, porcine circovirus, veterinary vaccine

\section{Introduction}

Porcine circovirus type 2 (PCV2) is one of the most pervasive viral pathogens repeatedly affecting the swine meat production industry worldwide as infection causes loss in pig production, mostly due to growth retardation, reduction in average daily weight gain and reproductive issues. Importantly this leads to immune suppression, increasing the risk of other pathogenic infections. PCV2 is also associated with the occurrence of postweaning multisystemic wasting syndrome (PMWS), porcine dermatitis and nephropathy syndrome (PDNS) and porcine respiratory disease complex (PRDC) (Karuppannan \& Opriessnig, 2017; Meng, 2013). Over the last few years, predominant genotype shifts have been observed, these include a shift from PCV2a to PCV2b in the mid-2000s and since 2010 a shift to PCV2d (Firth, Charleston, Duffy, Shapiro, \& Holmes, 2009; Giovanni Franzo, Cortey, Segalés, Hughes, \& Drigo, 2016; G. Franzo et al., 2015; Jang, Yoo, Kim, Yang, \& Lee, 2021; Thangthamniyom et al., 2017; Xiao, Halbur, \& Opriessnig, 2015). Currently, this strain is widely circulating in USA (Wang et al., 2020), China (Hou et al., 2019), Russia (Raev et al., 2019), Italy (G. Franzo et al., 2015), Korea (Jang et al., 2021) and Thailand (Thangthamniyom et al., 2017). The evolution of PCV2 has raised a debate on the cross-protection efficacy. Commercially available PCV2 vaccines, are mostly PCV2a- based vaccines which are produced based on inactivated whole PCV2 virus (Circovac) (EMA, 2007), inactivated baculovirus vector (Circumvent ${ }^{\circledR}$ PCV G2) (Merck), and baculovirusexpressed capsid (cap) protein (PORCILIS ${ }^{\circledR}$ ) (EMA, 2008; Merck, 2019). These production technologies are laborious, limited in expression level and relatively expensive for veterinary applications (Bernal, Carinhas, Yokomizo, Carrondo, \& Alves, 2009; Heldens et al., 2008; Kis, Shattock, Shah, \& Kontoravdi, 2019). To address these challenges, a simple, reliable, and cost-efficient production process is needed. One attractive choice is using $E$. coli microbial fermentation to express a PCV2d subunit vaccine.E. coli production can be performed to high cell density cultivation and the process can be readily conducted in large-scale with short production process time. Moreover, current processes render yields as high as g/L scales of products (Huang, Lin, \& Yang, 2012; Kim, Lee, Lee, \& Oh, 2013; Wu, Chen, Chi, Chien, \& Huang, 2016).

Recently, a novel PCV2d vaccine, and a laboratory-scale production process was developed in order to produce small quantities of test material for animal experiments and vaccines characterization (submitted manuscript under a review). However, for pig trials and manufacturing purposes, development of larger-scale production process is needed. Herein, for the first time, we demonstrate a simple and practical approach for large-scale biomanufacturing of this novel PCV2d subunit vaccine. The designed process covers fed-batch fermentation at bench- and pilot-scale, product recovery via homogenization followed by single-step purification using ion exchange chromatography. This production process has been evaluated by technology transfer to another production site in the UK and shown to achieve high yields of vaccine product. The successful development of this manufacturing platform enables local production of veterinary vaccines, thereby widening availability and accessibility. 


\section{Materials and Methods}

\subsection{Fermentation}

\subsubsection{E. coli cell banks and preculture in shake flasks}

Cell stocks of E. coli W3110 containing pET23/ptac $\Delta 2$-40PCV2d-His6 was received from the Robinson group at the University of Kent (UK) (submitted manuscript under a review). Research cell banks (RCB) were prepared by growing cells to an $\mathrm{OD}_{600}$ of $0.5-0.7$ in Terrific Broth (TB) (BD Difco?) containing $5 \mathrm{~g} / \mathrm{L}$ glycerol and $100 \mu \mathrm{g} / \mathrm{mL}$ ampicillin at $30^{\circ} \mathrm{C}$ and $200 \mathrm{rpm}$ in a shaking incubator (Innova43R, Eppendorf New Brunswick). Cells were mixed with $40 \% \mathrm{w} / \mathrm{v}$ glycerol in 1:1 ratio and stored at $-80^{\circ} \mathrm{C}$ for use in this whole study.

The preculture in shake flask started with $1 \%$ inoculation of RCB to $50 \mathrm{~mL}$ TB and incubated at $30^{\circ} \mathrm{C}$ and $200 \mathrm{rpm}$ overnight. For cell expansion to a pilot-scale fermenter, the first preculture was inoculated into a second preculture with $10 \%$ cells in $200 \mathrm{~mL}$ SM6Gc media with antibiotics and grown at $30^{\circ} \mathrm{C}$ and $200 \mathrm{rpm}$ until $\mathrm{OD}_{600}$ reached 5-7.

SM6Gc comprises of SM6 and its trace elements which were prepared separately. SM6 media consisted of $5.2 \mathrm{~g} / \mathrm{L}\left(\mathrm{NH}_{4}\right)_{2} \mathrm{SO}_{4}, 4.4 \mathrm{~g} / \mathrm{L} \mathrm{NaH} \mathrm{PO}_{4} \cdot \mathrm{H}_{2} \mathrm{O}, 4.03 \mathrm{~g} / \mathrm{L} \mathrm{KCl}, 1.04 \mathrm{~g} / \mathrm{L} \mathrm{MgSO}_{4} .7 \mathrm{H}_{2} \mathrm{O}, 4.55 \mathrm{~g} / \mathrm{L}$ Citric acid monohydrate, $0.25 \mathrm{~g} / \mathrm{L} \mathrm{CaCl}{ }_{2} \cdot 2 \mathrm{H}_{2} \mathrm{O}$, and $95 \mathrm{~g} / \mathrm{L}$ Glycerol. $\mathrm{pH}$ was adjusted to 7.0 using $25 \% \mathrm{NH}_{4} \mathrm{OH}$. The trace elements were prepared at $100 \mathrm{X}$ stock solutions containing $113.48 \mathrm{~g} / \mathrm{L}$ Citric acid monohydrate, $5.22 \mathrm{~g} / \mathrm{L} \mathrm{CaCl} \mathrm{Ca}_{2} .2 \mathrm{H}_{2} \mathrm{O}, 2.06 \mathrm{~g} / \mathrm{L} \mathrm{ZnSO}_{4} .7 \mathrm{H}_{2} \mathrm{O}, 2.028 \mathrm{~g} / \mathrm{L} \mathrm{MnSO}_{4} \cdot \mathrm{H}_{2} \mathrm{O}, 0.81 \mathrm{~g} / \mathrm{L} \mathrm{CuSO}_{4} .5 \mathrm{H}_{2} \mathrm{O}, 0.42 \mathrm{~g} / \mathrm{L}$ $\mathrm{CoSO}_{4} .7 \mathrm{H}_{2} \mathrm{O}, 10.06 \mathrm{~g} / \mathrm{L} \mathrm{FeCl} 3.6 \mathrm{H}_{2} \mathrm{O}, 0.03 \mathrm{~g} / \mathrm{L} \mathrm{H}_{3} \mathrm{BO}_{3}$, and $0.02 \mathrm{~g} / \mathrm{L} \mathrm{Na}_{2} \mathrm{MoO}_{4} \cdot 2 \mathrm{H}_{2} \mathrm{O}$. The trace element solutions were filtered through $0.22 \mu \mathrm{m}$ sterile syringe filter and stored in dark bottles at $4^{\circ} \mathrm{C}$. The filters and chemicals were all purchased from Merck KGaA unless otherwise stated.

\subsubsection{Fed-batch cultivations in stirred-tank fermenter}

The stirred-tank glass fermenters used in this work were 3.7 L Ralf Advanced (Bioengineering AG) equipped with a 2-flat-blade Rushton agitator, a 6-blade agitator for radial mixing, 4 stainless steel baffles and a ring sparger. 1.5 L SM6 media was transferred to the fermenter followed by autoclaving at $121^{\circ} \mathrm{C}$ for 20 minutes (VE150, Systec GmbH). $15 \mathrm{~mL}$ 100X trace elements solution was filter-sterilized via $0.22 \mu \mathrm{m}$ syringe filter into the vessel prior to inoculation. The $\mathrm{pH}$ set point of 7.0 was controlled by a cascade using internal peristaltic pumps for addition of $10 \% \mathrm{H}_{3} \mathrm{PO}_{4}$ or $25 \% \mathrm{NH}_{4} \mathrm{OH}$. The $\mathrm{pH}$ dead band was set to 0.1. Dissolved oxygen (DO) concentration, referred to as \%DO, was calibrated at 0 , by unplugging the probe's cable, and 100, by keeping the mixing speed at $1050 \mathrm{rpm}$ and the air flow rate at $60 \mathrm{Nl} / \mathrm{h}$. The \%DO setpoint was 30 and controlled by a cascade of agitation speeds (450-1050 rpm), air and $\mathrm{O}_{2}$ flow using a total gas flow of $1 \mathrm{vvm}$ (volume of gas sparged per fermenter working volume per minute). The starting temperature was set at $30^{\circ} \mathrm{C}$ and was reduced to $25^{\circ} \mathrm{C}$ once cells reached an $\mathrm{OD}_{600}$ of $60-70$. The temperature was controlled through perfused stainless-steel baffles connected to the heating circuit with a circulation pump, electrical heater, and cooling water valve. 5\% Antifoam 204 (Sigma-Aldrich, Inc) was used in preventing overflow of the media during cultivation through a control of a level probe and the peristaltic pump.

Fermentation was performed with a starting $\mathrm{OD}_{600}$ around 0.8. A series of supplements were added through a $0.22 \mu \mathrm{m}$ sterile syringe filter as follows; $1.972 \mathrm{~g} / \mathrm{L} \mathrm{MgSO}_{4} .7 \mathrm{H}_{2} \mathrm{O}$ when $\mathrm{OD}_{600}$ reached $38-42,1.164 \mathrm{~g} / \mathrm{L}$ $\mathrm{NaH}_{2} \mathrm{PO}_{4} \cdot \mathrm{H}_{2} \mathrm{O}$ at $\mathrm{OD}_{600}$ of $54-58$ and $1.63 \mathrm{~g} / \mathrm{L} \mathrm{NaH}_{2} \mathrm{PO}_{4} \cdot \mathrm{H}_{2} \mathrm{O}$ when starting the fed-batch process at $\mathrm{OD}_{600}$ around 66-70. The feeding media, $800 \mathrm{~g} / \mathrm{L}$ glycerol, was fed constantly at $0.15 \mathrm{~mL} / \mathrm{min}$ (per $1.5 \mathrm{~L}$ working volume) using the internal pump. Cells were induced with $0.039 \mathrm{~g} / \mathrm{L}$ Isopropyl $\beta$-d-1-thiogalactopyranoside (IPTG) when $\mathrm{OD}_{600}$ exceeded 75. Cells were then grown until $\mathrm{OD}_{600}$ reached 200, then the temperature was lowered to $15^{\circ} \mathrm{C}$ prior to proceeding to cell harvest by centrifugation at 7,500 xg for 30 minutes (LYNX 6000 , Thermo Fisher Scientific). Wet cell paste was collected and stored at $-20^{\circ} \mathrm{C}$ for downstream processing. Fermentation samples were collected throughout the cultivation for $\mathrm{OD}_{600}$ measurement. $1 \mathrm{~mL}$ cell suspension 
was taken, before and after induction, spun down and the pellet kept for SDS-PAGE and Western Blot analysis.

\subsubsection{Fed-batch cultivations in stirred-tank pilot-scale fermenter}

Fed-batch processes on a pilot scale were performed in a $42 \mathrm{~L}$ stainless-steel stirred-tank bioreactor (BIOSTATR D-DCU, Sartorius Stedim Biotech $\mathrm{GmbH}$ ) with 4 stainless-steel baffles and 3 six-bladed Rushton turbines. $20 \mathrm{~L}$ of SM6 media was prepared and transferred to the fermenter through an external peristaltic pump. Then automatic sterilization in place (SIP) was conducted using a recipe pre-programmed in BioPAT\& MFCS|win. After cooling down, $200 \mathrm{~mL} \mathrm{100X} \mathrm{trace} \mathrm{element} \mathrm{solution} \mathrm{was} \mathrm{added} \mathrm{to} \mathrm{the} \mathrm{sterile} \mathrm{media}$ using $0.2 \mu \mathrm{m}$ sterile disc filter (Sartolabß P20, Sartorius AG). The operating conditions were set as described above with a slight change in \%DO cascade where agitation ranged from 250 to $800 \mathrm{rpm}$ while the total gas flow was maintained at $1 \mathrm{vvm}$. Prior to the inoculation, the media was held overnight to verify the sterility. Then inoculation was carried out using the second preculture to obtain an initial $\mathrm{OD}_{600}$ of around 0.8. Supplements, feeding media and IPTG were added as described above. The $800 \mathrm{~g} / \mathrm{L}$ glycerol was fed constantly at $2 \mathrm{~mL} / \mathrm{min}$ (per $20 \mathrm{~L}$ working volume). Fermentation was terminated after cells were grown for more than 48 hours and OD600 was over 200. Wet cell paste was collected after centrifugation and stored for future use. Samples were collected and analyzed described in Sample preparation and analytical methods session.

\subsection{Cell disruption and filtration}

$15 \%$ of E. coli W3110 producing PCV2d capsid protein wet cell paste was resuspended in resuspension buffer (50mM Tris-HCl, 2.5mM EDTA, pH 7.0) using a disperser at 3,000 rpm, 15 min (T50 digital ULTRATURRAX@, IKA). The resuspension cell sample was lysed by cell disruption using a high-pressure homogenizer (TS Series 4kW, Constant Systems LTD) at 700 bars for 10 passages until low viscosity of lysed cells was observed. Cell debris was separated by centrifugation at $20,000 \mathrm{xg}$ for 30 minutes at $10^{\circ} \mathrm{C}$. The supernatant was collected and filtered through a depth filter (Supracap 50 PDH4, Pall) and a $0.45 \mu \mathrm{m}$ PES membrane disc filters (Supor@, Pall). A turbidity meter (L100Q, Hach) was used to measure sample clarification prior to applying sample onto the chromatographic column.

\subsection{Cation exchange chromatography}

Cation exchange chromatography was conducted as one step purification (ÄKTA Pure 150, Cytiva). A HiScale 16/40 column (Cytiva) was packed with SP Sepharose Fast Flow resin (Cytiva) to $20 \mathrm{~cm}$ bed height, requiring $40 \mathrm{~mL}$ of resin. Column efficiency was tested according to Cytiva's protocol. The flow rate was kept constant at linear velocity of $300 \mathrm{~cm} / \mathrm{h}$ for the entire run. The column was equilibrated with $50 \mathrm{mM}$ Tris-HCl, $\mathrm{pH} 7.0$ in 3 column volumes (CV). The clarified supernatant from the product recovery step was applied onto the column for $5 \mathrm{CV}$ using the sample pump. Unbound proteins and impurities were first washed with $4 \mathrm{CV}$ of equilibration buffer and second washed with a step gradient at $45 \%$ of elution buffer $(50 \mathrm{mM}$ Tris-HCl, $1 \mathrm{M} \mathrm{NaCl}, \mathrm{pH}$ 7.0) for another $4 \mathrm{CV}$. PCV2d was eluted at $90 \%$ of elution buffer for $4 \mathrm{CV}$. Flow through, washing steps and elutions were all collected in 40-, 40- and 10-mL fractions, respectively. The purified fractions were collected for SDS-PAGE, Western Blot and Bradford analysis.

\subsection{Analytical methods}

Cell pellets from fermentation runs were resuspended in $50 \mathrm{mM}$ Tris-HCl, $2.5 \mathrm{mM}$ EDTA, pH 7.0 with the same volume that was taken out after centrifugation. Resuspended cells were lysed by sonication using a microtip $(6.4 \mathrm{~mm})$ with $70 \%$ amplitude at 5 seconds On-time and 10 seconds Off-time for total of 1 minute On-time (4C15, BRANSON). The lysed samples were centrifuged at 14,000 rpm for 10 minutes. The supernatant and inclusion bodies (IB) were separately collected and mixed with 4x Laemmli sample buffer 
with reducing agent, 2-mercaptoethanol, then boiled for 10 minutes. For SDS-PAGE and Western blot 12\% SDS-PAGE gels loaded and followed by protein transfer onto a polyvinylidene difluoride membrane. The membrane was blocked overnight with $3 \%$ blotting-grade blocker in Tris-buffered saline with $1 \%$ Tween20 (TBST) at $4^{\circ} \mathrm{C}$. After washing with TBST, the membrane was incubated for 1 hour with anti-Porcine circovirus antibody at 1:2,000,000, obtained from Robinson's lab at University of Kent, UK. The secondary antibody, Goat Anti-rabbit IgG H\&L (Abcam), was used at 1:10,000 dilution. The membrane was imaged on ChemiDoc (Bio-Rad) with Western ECL Substrate. Precision Plus protein dual color standard was used as a molecular weight marker. Protein concentrations were determined using Bradford assay. All reagents were sourced from Bio-Rad unless otherwise stated.

\section{Results and Discussion}

The Global Challenges Research Fund (GCRF) consortium has recently presented the small-scale production of a relatively inexpensive PCV2d vaccine candidate with a yield of over $1 \mathrm{~g}$ purified PCV2d-based antigen per litre bacterial culture (manuscript under review). The vaccine candidate was shown to effectively induce PCV2d-neutralising antibodies in immunised animals, indicating significant potential as a new vaccine candidate.

Here, we present proof that this vaccine candidate can be easily manufactured at commercial scale. The process flow diagram for the PCV2d subunit vaccine production developed in this work is summarized in Figure 1. The workflow requires 3 steps: fermentation, cell disruption followed by filtration and cation exchange chromatography. In-process controls, as indicated in the diagram, were included in each step, using analytical methods such as $\mathrm{OD}_{600}$, SDS-PAGE, Western blot, Turbidity and Bradford assay.

\subsection{PCV2d fermentation - from bench scale to pilot scale}

At first, fermentation of PCV2d was attempted at $1.5 \mathrm{~L}$ working volume. Seed trains were prepared in $50 \mathrm{~mL} \mathrm{~TB}$ reaching an overnight $\mathrm{OD}_{600}$ of 10-12 and transferred into each fermenter where cells were grown in chemically defined media (SM6Gc). Defined media provides benefits over other media, such as reducing batch-to-batch variability observed in complex media as well as increasing process control for simple downstream processing. This could lower vaccine production costs (Alfano, Pennybaker, Halfmann, \& Huang, 2020; Stanbury, Whitaker, \& Hall, 2017).

Batch fermentations were run for 24 hours and yielded $\mathrm{OD}_{600}$ values of approximately 60 in batch 01 and 02, and 80 in batch 03 and 04 . After this phase, fed-batch was performed in constant mode. The calculated specific growth rates during the exponential phase of these four batches were in the range of $0.07-0.12 \mathrm{~h}^{-1}$. At the end of the fermentation, cells densities reached as high as $\mathrm{OD}_{600}$ of 230 , the lowest cell density was observed at $\mathrm{OD}_{600}$ of 170 (Figure $2 \mathrm{~A}$ ). This variation between batches resulted in the calculated wet cell paste to culture weight ranging from 141 to $232 \mathrm{~g} / \mathrm{kg}$ broth. This range was relatively wide possibly due to the different liquid content in cell paste though it is acceptable in this application. PCV2d was well expressed in both insoluble (inclusion body) and soluble fractions in all batches as seen on the Coomassie gels with a band migrating at the expected molecular weight of $25 \mathrm{kDa}$ for PCV2d (Figure 2B). These small-scale fermentations provided the operating conditions for the upstream process and demonstrated reproducibility in protein expression, despite variations in growth. The conditions were then applied for the development of a large-scale fermentation process.

To this end and using the established bench scale parameters, the PCV2d vaccine was produced in larger scale to demonstrate the production capability in a $42 \mathrm{~L}$ stainless-steel fermenter with $20 \mathrm{~L}$ initial working volume. The growth rate in large scale fermentation was shown to be comparable to the $1.5 \mathrm{~L}$ fermentation runs shown in Figure 2A. During the exponential phase, the calculated $\mu$ was $0.15 \mathrm{~h}^{-1}$. Cells were grown to an $\mathrm{OD}_{600}$ of 220 corresponding to $6.59 \mathrm{~kg}$ wet cell paste with a total cultivation weight of $27.99 \mathrm{~kg}$. This resulted in the calculation of $235 \mathrm{~g}$ wet cell per $\mathrm{kg}$ culture weight. Samples from various time points 
after IPTG induction were analyzed for PCV2d expression on SDS PAGE and Western blot as illustrated in Figure 2C. Soluble PCV2d was observed at 8 hours post induction both in the insoluble and soluble fractions. The soluble fraction provided enough material for straightforward downstream processing and eliminated the need to isolate protein from inclusion bodies.

To illustrate process transferability and reproducibility of this simple upstream process, large-scale production was carried out at in parallel at the consortium partner site in the UK as shown in Figure 2A (BL01 at KMUTT and BL02 at UCL).

\subsection{Cell disruption and filtration}

Next, PCV2d was isolated and purified from $60 \mathrm{~g}$ cell mass derived from large scale fermentations. Cells were disrupted by homogenization in continuous mode until low viscosity of the mixture was observed, which was established to be after 10 passages. After centrifugation was carried out for liquid-solid separation, the supernatant fraction was then collected. A series of depth filtration and membrane filtration steps were then performed, which was filtered through $0.5-15 \mu \mathrm{m}$ retention rating filters and $0.45 \mu \mathrm{m}$ membrane filters. The turbidity of the filtered sample was measured at 215 NTU. Although this seemed to be rather high, no untypical increase in column pressure was observed during sample application on the ion exchange column.

\subsection{Cation exchange chromatography}

The PCV2d protein has an isoelectric point (PI) of 9.4. Thus, a cation exchange column with bind/elute mode at $\mathrm{pH} 7.0$ was selected for downstream purification. SP Sepharose Fast Flow has been widely used in preparative protein separations and is well known for high speed and low cost. $200 \mathrm{~mL}$ of clarified sample was loaded with a flow rate at $10 \mathrm{~mL} / \mathrm{min}$. The chromatogram shown in Figure $4 \mathrm{~A}$ demonstrates that the peak at conductivity $>60 \mathrm{mS} / \mathrm{cm}$ was well separated from the peaks observed in the washing step at conductivity $20-45 \mathrm{mS} / \mathrm{cm}$. When the peak fractions were analyzed by $12 \%$ SDS-PAGE and Western Blot (Figure 4B) it was confirmed that the fractions from $20-45 \mathrm{mS} / \mathrm{cm}$ conductivity were impurities. In the Western blot a much lower than expected molecular weight band was seen which could be a protein degradation product. PCV2d was co-eluted with lower molecular weight proteins in the first few fractions but later fractions contained the pure product. Fraction number E5 - E13 were pooled and the concentration determined to be $0.8 \mathrm{mg} / \mathrm{mL}$ in $90 \mathrm{~mL}$. This corresponds to a calculated yield of $16 \mathrm{~g}$ of pure PCV2d for one large-scale fermentation run or a yield of $0.8 \mathrm{~g} / \mathrm{L}(16 \mathrm{~g}$ per $20 \mathrm{~L})$. This result is comparable with our recently reported small-scale yield of $1 \mathrm{~g} / \mathrm{L}$ (GCRF consortium, manuscript under review) and we therefore provide proof of scalability of the process. One full dose of PCV2d vaccine requires $80 \mu \mathrm{g}$ of PCV2d protein, as reported by Sno, Cox, and Segers (2020). The protein yield from a 20 L scale fermentation is therefore sufficient to vaccinate as many as 200,000 pigs with one dose.

\section{Conclusion}

Here, we have presented a biomanufacturing process that is simple, easily transferrable, and expandable to a large-scale E. coliplatform producing protein subunit vaccines for PCV2d. All steps were carefully evaluated and developed with the aim of avoiding excessive investment costs in low- and middle-income regions or high processing costs while maintaining high quality for veterinary applications.

\section{Acknowledgements}

This work was supported by UK Research and Innovation 'Global Challenges Research Fund' grant BB/P02789X/1. We would like to thank all member in this GCRF consortium for their greatly supports. 


\section{Conflicts of interests}

The authors declare no conflicts of interests.

\section{Author contributions}

SN, TK, NL, PE and SS designed, performed experiments and analyzed data. SN and LH prepared figures. SN, LH and SF wrote the paper. All authors read and approved the final manuscript. LH and SF acquired funding.

\section{References}

Alfano, R., Pennybaker, A., Halfmann, P., \& Huang, C. Y.-H. (2020). Formulation and production of a bloodfree and chemically defined virus production media for VERO cells. Biotechnology and Bioengineering, 117 (11), 3277-3285. doi:10.1002/bit.27486

Bernal, V., Carinhas, N., Yokomizo, A. Y., Carrondo, M. J. T., \& Alves, P. M. (2009). Cell density effect in the baculovirus-insect cells system: A quantitative analysis of energetic metabolism.Biotechnology and Bioengineering, 104 (1), 162-180. doi:10.1002/bit.22364

EMA. (2007). Circovac Adjuvanted Inactivated Vaccine Against Porcine Circovirus Type 2 . Retrieved from

Firth, C., Charleston, M. A., Duffy, S., Shapiro, B., \& Holmes, E. C. (2009). Insights into the Evolutionary History of an Emerging Livestock Pathogen: Porcine Circovirus 2. Journal of Virology, 83 (24), 12813-12821. doi:10.1128/jvi.01719-09

Franzo, G., Cortey, M., Segalés, J., Hughes, J., \& Drigo, M. (2016). Phylodynamic analysis of porcine circovirus type 2 reveals global waves of emerging genotypes and the circulation of recombinant forms. Molecular Phylogenetics and Evolution, 100 , 269-280. doi:10.1016/j.ympev.2016.04.028

Franzo, G., Tucciarone, C. M., Dotto, G., Gigli, A., Ceglie, L., \& Drigo, M. (2015). International trades, local spread and viral evolution: the case of porcine circovirus type 2 (PCV2) strains heterogeneity in Italy. Infect Genet Evol, 32 , 409-415. doi:10.1016/j.meegid.2015.04.004

Heldens, J. G. M., Patel, J. R., Chanter, N., Ten Thij, G. J., Gravendijck, M., Schijns, V. E. J. C., . . . Schetters, T. P. M. (2008). Veterinary vaccine development from an industrial perspective. Veterinary journal (London, England : 1997), 178 (1), 7-20. doi:10.1016/j.tvjl.2007.11.009

Hou, Z., Wang, H., Feng, Y., Song, M., Li, Q., \& Li, J. (2019). Genetic variation and phylogenetic analysis of Porcine circovirus type 2 in China from 2016 to 2018. Acta virologica, 63 (4), 459-468.

Huang, C.-J., Lin, H., \& Yang, X. (2012). Industrial production of recombinant therapeutics in Escherichia coli and its recent advancements. Journal of Industrial Microbiology and Biotechnology, 39 (3), 383-399. doi:10.1007/s10295-011-1082-9

Jang, G., Yoo, H., Kim, Y., Yang, K., \& Lee, C. (2021). Genetic and phylogenetic analysis of porcine circovirus type 2 on Jeju Island, South Korea, 2019-2020: evidence of a novel intergenotypic recombinant.Arch Virol, 166 (4), 1093-1102. doi:10.1007/s00705-020-04948-1

Karuppannan, A. K., \& Opriessnig, T. (2017). Porcine Circovirus Type 2 (PCV2) Vaccines in the Context of Current Molecular Epidemiology. Viruses, 9 (5). doi:10.3390/v9050099

Kim, C. K., Lee, C. H., Lee, S.-B., \& Oh, J.-W. (2013). Simplified Large-Scale Refolding, Purification, and Characterization of Recombinant Human Granulocyte-Colony Stimulating Factor in Escherichia coli.PLOS ONE, 8 (11), e80109. doi:10.1371/journal.pone.0080109 
Kis, Z., Shattock, R., Shah, N., \& Kontoravdi, C. (2019). Emerging Technologies for Low-Cost, Rapid Vaccine Manufacture.Biotechnology Journal, 14 (1), 1800376. doi:10.1002/biot.201800376

Meng, X. J. (2013). Porcine circovirus type 2 (PCV2): pathogenesis and interaction with the immune system. Annu Rev Anim Biosci, 1 , 43-64. doi:10.1146/annurev-animal-031412-103720

Merck. CIRCUMVENTR PCV G2 . Retrieved from

Raev, S., Yuzhakov, A., Alekseev, K., Kostina, L., Gulyukin, M., Stepanova, T., . . Aliper, T. (2019). Transmission of porcine circovirus genotype type 2 (PCV2) in Russia and genotype association (PCV2d) with porcine dermatitis and nephropathy syndrome (PDNS). Paper presented at the IOP Conference Series: Earth and Environmental Science.

Sno, M., Cox, E., \& Segers, R. P. A. M. (2020). United States Patent No. US20200206340A1.

Stanbury, P. F., Whitaker, A., \& Hall, S. J. (2017). Chapter 4 - Media for industrial fermentations. In P. F. Stanbury, A. Whitaker, \& S. J. Hall (Eds.), Principles of Fermentation Technology (Third Edition) (pp. 213-272). Oxford: Butterworth-Heinemann.

Thangthamniyom, N., Sangthong, P., Poolperm, P., Thanantong, N., Boonsoongnern, A., Hansoongnern, P., . . Lekcharoensuk, P. (2017). Genetic diversity of porcine circovirus type 2 (PCV2) in Thailand during 2009-2015. Vet Microbiol, 208 , 239-246. doi:10.1016/j.vetmic.2017.08.006

Wang, Y., Noll, L., Lu, N., Porter, E., Stoy, C., Zheng, W., . . . Bai, J. (2020). Genetic diversity and prevalence of porcine circovirus type 3 (PCV3) and type 2 (PCV2) in the Midwest of the USA during 2016-2018. Transboundary and emerging diseases, 67 (3), 1284-1294.

Wu, P.-C., Chen, T.-Y., Chi, J.-N., Chien, M.-S., \& Huang, C. (2016). Efficient expression and purification of porcine circovirus type 2 virus-like particles in Escherichia coli. Journal of Biotechnology, 220 , 78-85. doi:10.1016/j.jbiotec.2016.01.017

Xiao, C.-T., Halbur, P. G., \& Opriessnig, T. (2015). Global molecular genetic analysis of porcine circovirus type 2 (PCV2) sequences confirms the presence of four main PCV2 genotypes and reveals a rapid increase of PCV2d. Journal of General Virology, 96 (7), 1830-1841. doi:10.1099/vir.0.000100 


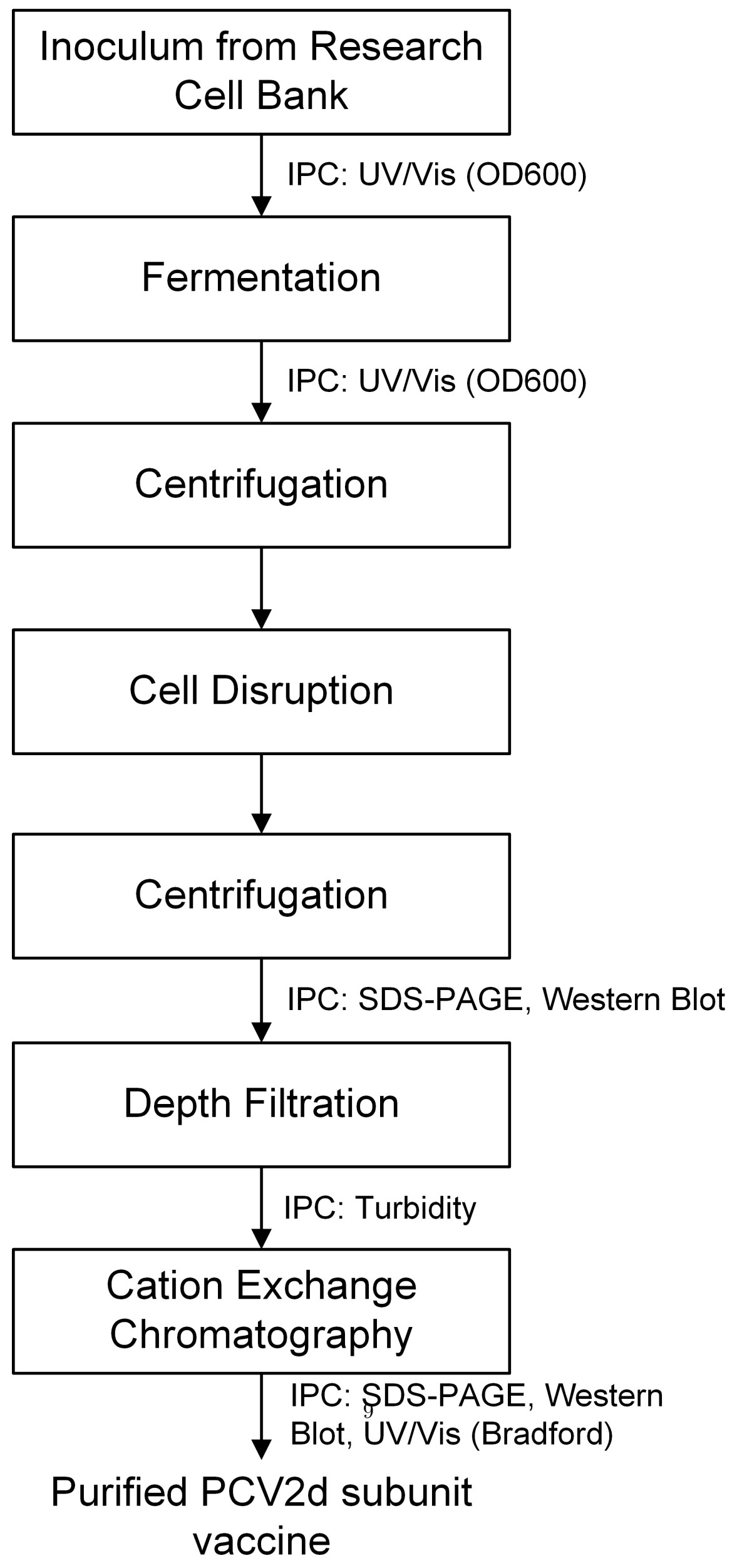



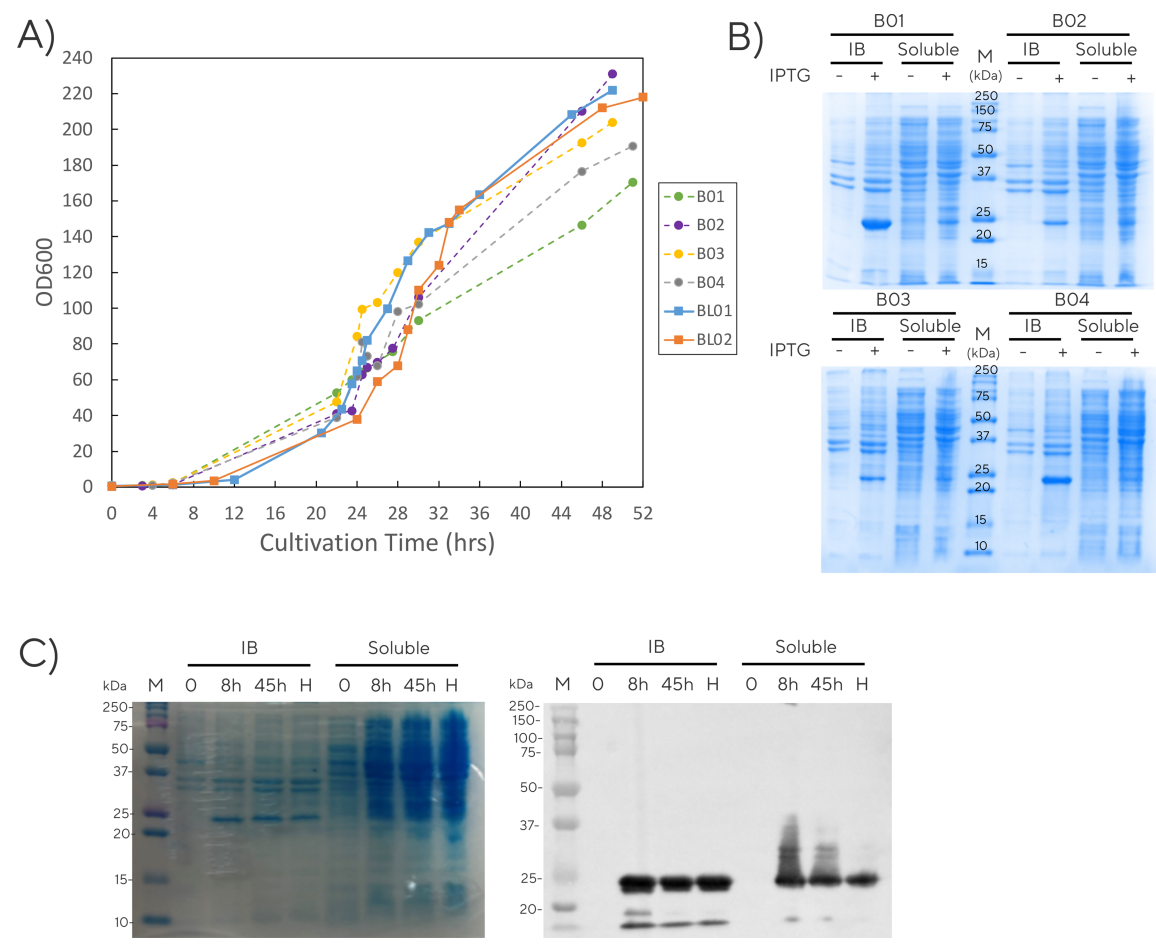
A)

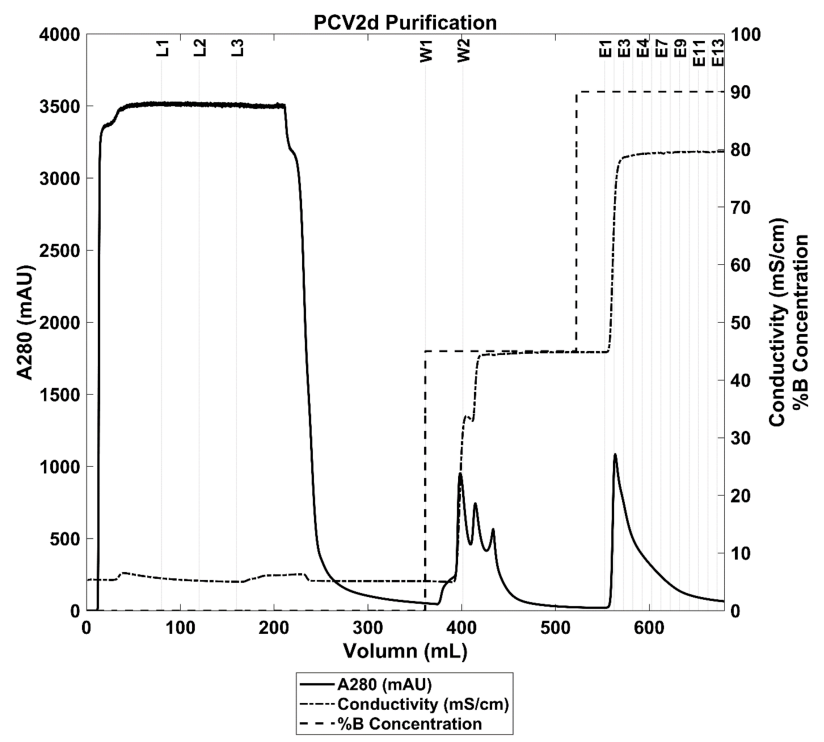

B)

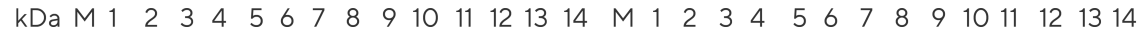
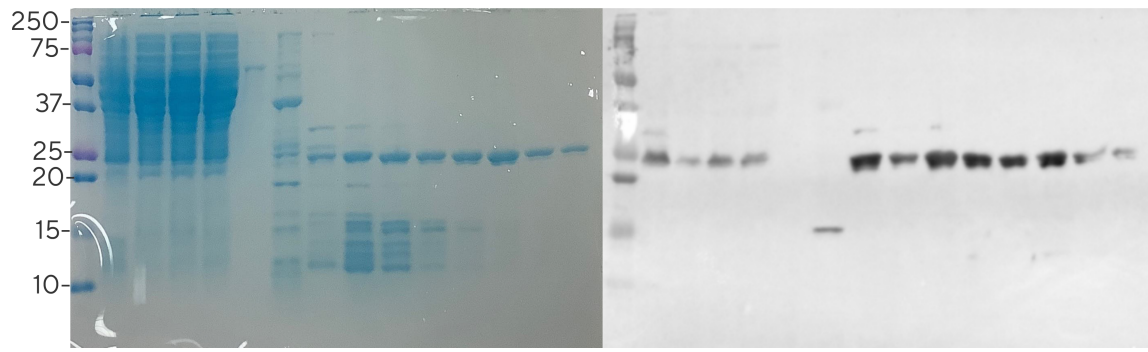